\title{
Analisis dan Desain Antena Mikrostrip untuk Komunikasi Satelit pada Frekuensi Ka-Band
}

\author{
Fariany Rizqa ${ }^{*}$, Dharu Arseno, Trasma Yunita
}

Prodi S1 Teknik Telekomunikasi, Fakultas Teknik Elektro, Universitas Telkom

*email: farianyrizqa24@gmail.com

\begin{abstract}
Satellite technology is a telecommunications technology where the satellite is a communication device placed in space and requires the allocation of the frequency spectrum for telecommunications services. The most widely used frequencies for satellite communication are the $\mathrm{C}$-Band frequency (4 GHz to $8 \mathrm{GHz}$ ) and the $\mathrm{Ku}$-Band frequency (12 GHz to $18 \mathrm{GHz}$ ). Also, Ka-Band frequency $(26,5 \mathrm{GHz}$ to $40 \mathrm{GHz})$ is the center of attention in the telecommunications industry nowadays because it has a large enough bandwidth to accommodate more service capacity. In this article, a microstrip antenna with a rectangular patch of four elements (array 2x2) has been designed using line feed rationing techniques that work at a frequency of 29,25 $\mathrm{GHz}$ (Ka-Band) for satellite communication. An appropriate antenna dimension is required so that the antenna can work and has a good performance at the expected frequency. Simulation results show a return loss value of $-43,052 d B$, VSWR is worth 1,014 with a bandwidth of 2,728 GHz. In addition, the resulting gain value is 7,823 dB with directional radiation patterns and ellipse polarization.
\end{abstract}

Keywords - Microstrip Antenna, Array, Satellite Communication, Ka-Band

\section{Pendahuluan}

Perkembangan teknologi informasi menyebabkan kebutuhan informasi terus meningkat, sehingga perlu adanya akses informasi yang dapat menjangkau wilayah luas. Maka dari itu, perlu adanya teknologi yang dapat menghantarkan sinyal komunikasi tanpa terhalang obstacle salah satunya adalah teknologi satelit[1]. Satelit merupakan suatu perangkat komunikasi yang ditempatkan diluar angkasa. Satelit memiliki fungsi yaitu sebagai penerus sinyal microwave atau repeater sehingga memungkinkan untuk sejumlah pengguna layanan telekomunikasi dapat saling bertukar informasi selama perangkat pelanggan terhubung dengan stasiun bumi[2]. Di antara beberapa frekuensi yang tersedia, frekuensi C-Band dengan rentang $4 \mathrm{GHz}$ hingga $8 \mathrm{GHz}$ dan $\mathrm{Ku}-\mathrm{Band}$ dengan rentang $12 \mathrm{GHz}$ hingga $18 \mathrm{GHz}$ adalah frekuensi yang paling banyak digunakan untuk komunikasi satelit. Untuk kalangan industri telekomunikasi, frekuensi Ka-Band menjadi pusat perhatian saat ini. Dimana Frekuensi KaBand memiliki rentang 26,5 GHz hingga $40 \mathrm{GHz}$.

Kelebihan dari frekuensi Ka-Band adalah memiliki bandwidth yang cukup besar sehingga dapat menampung kapasitas layanan lebih banyak[3]. Penelitian sebelumnya menunjukkan bahwa frekuensi Ka-Band merupakan solusi yang dihadapi pada komunikasi satelit. Peningkatan suatu frekuensi akan menghasilkan kapasitas bandwidth menjadi lebih besar dan lebar[4]. Pada artikel ini merancang dan mendesain antena mikrostrip pada antenna design software dengan patch rectangular yang berjumlah empat (array 2x2) elemen dengan frekuensi sebesar 29,25 GHz yang dapat bekerja pada frekuensi Ka-Band untuk mendukung penggunaan komunikasi satelit.

Manuscript submitted 24 December 2019; revised 10 January 2020; accepted 14 January 2020.

Published 16 January 2020; http://dx.doi.org/10.28989/avitec.v2i1.590 


\section{Tinjauan Pustaka}

\subsection{Sistem Komunikasi Satelit}

Teknologi satelit merupakan salah satu teknologi telekomunikasi nirkabel selain sistem komunikasi seluler. Teknologi satelit diharapkan mampu menjangkau wilayah yang luas walaupun terdapat perbukitan, pegunungan ataupun hutan dimana wilayah tersebut sulit dijangkau dengan telekomunikasi kabel atau wired maupun teknologi seluler. Satelit mengorbit pada bumi dikategorikan menjadi beberapa macam klasifikasi yaitu GEO (Geostationery Earth Orbit), MEO (Medium Earth Orbit), dan LEO (Low Earth Orbit)[5]. Teknologi satelit dapat memberikan beberapa layanan seperti televise, siaran radio, koneksi untuk jaringan telepon, penerbangan, dan lainnya.

\subsection{Frekuensi Ka-Band}

Teknologi satelit membutuhkan alokasi spektrum frekuensi untuk mengadakan layanan komunikasi. Topik yang menjadi perhatian di kalangan industri telekomunikasi saat ini adalah frekuensi Ka-Band yang memiliki rentang dari $26,5 \mathrm{GHz}$ hingga $40 \mathrm{GHz}$ dengan frekuensi uplink sebesar 27,5 GHz hingga $31 \mathrm{GHz}$. Ka-Band memiliki bandwidth lebih besar yang dapat menampung kapasitas layanan lebih banyak[3]. Ka-Band merupakan salah satu rentang frekuensi yang digunakan untuk komunikasi satelit yang berada pada rentang frekuensi diatas $10 \mathrm{GHz}$. Pita frekuensi untuk komunikasi satelit ditunjukkan pada Gambar 1.

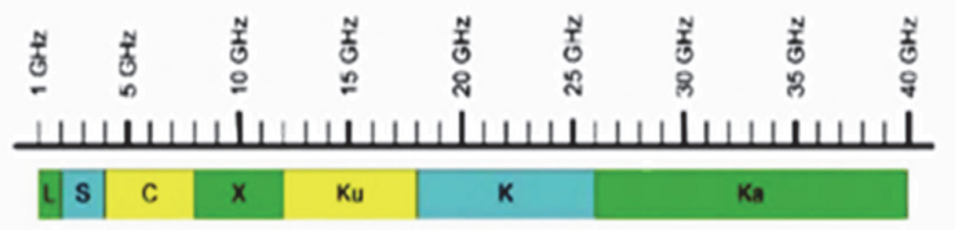

Gambar 1. Pita Frekuensi untuk Komunikasi Satelit[1].

\subsection{Antena}

Berdasarkan IEEE Standard Definitions of Term for Antenna, antena adalah perangkat yang dapat mengirim dan menerima gelombang radio[6]. Dapat diartikan juga sebagai konduktor elektrik yang baik digunakan untuk meradiasikan energi elektromagnetik. Antena dapat mengubah sinyal-sinyal listrik menjadi gelombang elektromagnetik dan memancarkan ke udara bebas ataupun sebaliknya. Biasanya antena terbuat dari logam berbentuk batang ataupun kawat dan memiliki fungsi untuk memamcarkan ataupun merima gelombang[7].

\subsection{Antena Mikrostrip Rectangular}

Antena mikrostrip merupakan antena yang populer saat ini karena biayanya yang murah, ukurannya kecil, dan mudah difabrikasi. Selain itu, antena mikrostrip mudah dalam penyesuaian frekuensi resonansi, impedansi input, polarisasi, dan pola radiasi. Antena mikrostrip memiliki komponen ground plane yang terbuat dari copper berada di lapisan paling bawah yang berfungsi sebagai pemantul sempurna. Substrate diatasnya memiliki konstanta dielektrik $\left(\varepsilon_{r}\right)$, dan tebal substrate $(h)$. Desain Antena Mikrostrip Rectangular dapat ditunjukkan pada Gambar 2. 


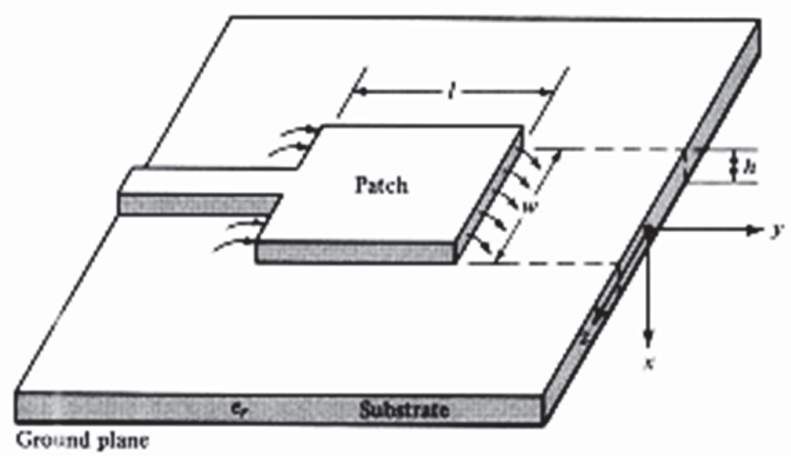

Gambar 2. Desain Antena Mikrostrip Rectangular[9].

Ada pula patch terletak paling atas yang berfungsi sebagai radiator yang memiliki bentuk yaitu rectangular, square, circular, dan lainnya[8]. Bentuk Patch rectangular mudah untuk dilakukan analisis dan paling akurat untuk substrate yang tipis[6]. Ukuran dimensi antena mikrostrip dapat dicari melalui perhitungan dari rumus yang telah disederhanakan.

Untuk menentukan ukuran dimensi antena, dapat menggunakan persamaan berikut:

a. Lebar patch $(W p)$

$$
W p=\frac{c}{2 f} \sqrt{\frac{2}{\varepsilon r+1}}
$$

b. Panjang patch $(L p)$

$$
\begin{aligned}
& L_{\mathrm{eff}}=\frac{c}{2 f \sqrt{\varepsilon e f f}} \\
& \varepsilon_{\mathrm{eff}}=\frac{\varepsilon r+1}{2}+\frac{\varepsilon r-1}{2}\left[\frac{1}{\sqrt{1+\frac{12 h}{W p}}}\right] \\
& \Delta L=0,412 h \frac{(\varepsilon e f f+0,3)\left(\frac{W p}{h}+0,264\right)}{(\varepsilon e f f-0,258)\left(\frac{W p}{h}+0,8\right)} \\
& L p=L_{\mathrm{eff}}-2 \Delta L
\end{aligned}
$$

\subsection{Teknik Pencatuan}

Salah satu teknik pencatuan antena mikrostrip adalah line feed. Bahan yang digunakan line feed sama seperti bahan yang digunakan pada patch[8]. Spesifikasi yang harus ditentukan dari line feed adalah impedansi karakteristik (Zo) yang dapat memperlebar microstrip line feed. Berikut persamaan-persamaan untuk menentukan ukuran dimensi line feed dengan Zo sebesar $50 \Omega, 70.7 \Omega$, dan $100 \Omega$.

a. Lebar line feed $(W f)$

$$
\begin{aligned}
& B=\frac{377 \pi}{2 x Z o x \sqrt{\varepsilon r}} \\
& W f=\frac{2 h}{\pi}\left\{B-1-\ln (2 B-1)+\frac{\varepsilon r-1}{2 \varepsilon r}\left[\ln (B-1)+0,39-\frac{0,61}{\varepsilon r}\right]\right\}
\end{aligned}
$$


b. $\quad$ Panjang line feed $(L f)$

$$
\begin{aligned}
& \lambda_{\mathrm{o}}=\frac{c}{f} \\
& \mathrm{G}_{1}=\frac{1}{90}\left[\frac{W p}{\lambda_{\mathrm{o}}}\right]^{2} \\
& R_{\text {in }}\left(\mathrm{y}=\mathrm{y}_{\mathrm{o}}\right)=\frac{1}{2 G 1} \cos ^{2}\left(\frac{\pi}{L p} x L f\right)
\end{aligned}
$$

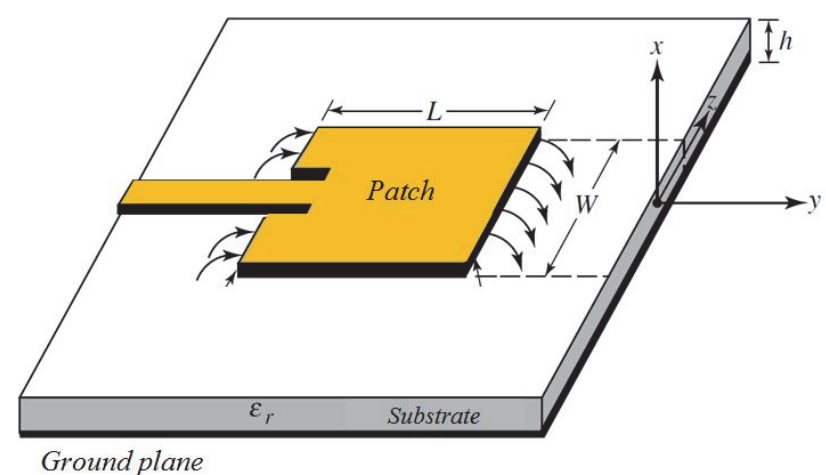

Gambar 3. Antena Mikrostrip dengan Inset Feed[10].

Penggunaan inset feed sebagaimana Gambar 3 bertujuan untuk mempermudah dalam pengontrolan impedansi input pada antena mikrostrip dengan memperhatikan lebar inset feed $\left(\mathrm{x}_{\mathrm{o}}\right)$ dan panjang inset feed $\left(\mathrm{y}_{\mathrm{o}}\right)$ sebesar $1 \mathrm{~mm}$. Rumus yang digunakan untuk menentukan ukuran $\left(\mathrm{x}_{\mathrm{o}}\right)$ yaitu sebagai berikut:

$$
\begin{aligned}
& \mathrm{x}_{\circ}=\frac{L p}{\pi} \operatorname{vos}^{-1} \sqrt{\frac{z o}{R i n}} \\
& W g=6 h+W p \\
& L g=6 h+L p
\end{aligned}
$$

Sedangkan untuk menentukan lebar ground plane $(W g)$ dan panjang ground plane $(L g)$ dapat menggunakan persamaan (12) dan persamaan (13).

\subsection{Antena Susun (Array)}

Antena array adalah antena susunan dari beberapa antena yang identik pada bagian patch. Salah satu tujuan pembuatan array yaitu untuk meningkatkan nilai gain antena. Umumnya pada antena satu elemen memiliki pola radiasi yang lebar teapi menghasilkan nilai gain rendah[11]. Salah satu aplikasi yang membutuhkan nilai gain tinggi yaitu komunikasi satelit. 


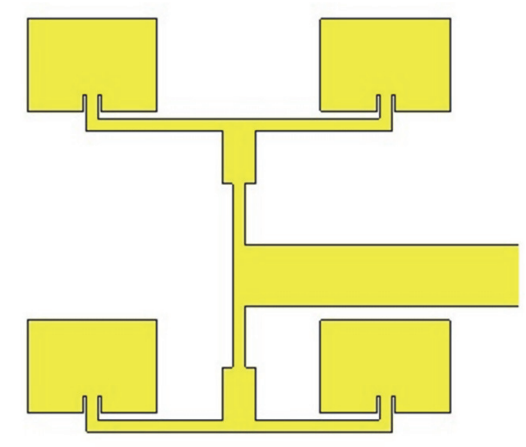

Gambar 4. Antena Mikrostrip Rectangular Patch Array 2x2[12].

Terdapat junction horizontal sebagai penghubung antara feed line $100 \Omega$. Untuk menentukan lebar junction horizontal $(W j)$ dapat menggunakan persamaan berikut:

$$
W j=d=\frac{\lambda o}{2}
$$

Sedangkan untuk junction vertical sebagai penghubung antara feed line $70.7 \Omega$. Untuk panjang junction vertical $(L f \mathrm{j})$ dapat menggunakan persamaan berikut:

$$
L f_{\mathrm{j}}=2 \times L f_{(\mathrm{Zo}=100 \Omega)}
$$

\subsection{Parameter Antena}

Kinerja sebuah antena dapat dilihat dari nilai-nilai parameter yang dihasilkan, karena parameter tersebut berkaitan satu sama lain. Beberapa parameter yang digunakan untuk menganalisis suatu antena antara lain:

1. Return loss, merupakan perbandingan antara amplitudo gelombang pantul terhadap gelombang yang dikirim[7].

2. VSWR (Voltage Standing Wave Ratio), adalah perbandingan antara tegangan maksimum dengan tegangan minimum pada gelombang berdiri.

3. Bandwidth, adalah rentang frekeuensi dimana antena dapar memancarkan dan menerima daya. Untuk menentukan nilai bandwidth, dapat dilihat dari rentang frekuensi dengan batas maksimum VSWR[13].

4. Gain, merupakan perbandingan antara daya yang difokuskan oleh antena pada arah tertentu dengan daya yang dipancarkan antena referensi[13].

\subsection{Pola Radiasi Antena}

Pola radiasi merupakan penggambaran grafis sifat-sifat pancaran energi antena sebagai fungsi koordinat-koordinat ruang[7]. Salah satu pola radiasi adalah directional antenna atau antena terarah yang dapat memancarkan atau menerima gelombang elektromagnetik pada arah tertentu dan dapat menjangkau jarak jauh.

\subsection{Polarisasi Antena}

Polarisasi merupakan arah getaran golombang dari antena. Berdasarkan nilai axial ratio, polarisasi dikelompokkan menjadi tiga bagian yaitu:

1. Polarisasi circular, memiliki medan listrik yang sama tetapi berjalan berputar membentuk lingkaran dan dapat terjadi secara horizontal maupun vertical yang memiliki rentang $0 \mathrm{~dB} \leq|\mathrm{AR}|<3 \mathrm{~dB}$.

2. Polarisasi ellipse, terjadi ketika gelombang berubah terhadap waktu memiliki medan elektrik dengan rentang $3 \mathrm{~dB} \leq|\mathrm{AR}|<40 \mathrm{~dB}$. 
3. Polarisasi linier, dimana antena akan menerima sinyal sama besar dan hanya dapat secara horizontal atau vertical saja dengan rentang $|\mathrm{AR}| \geq 40 \mathrm{~dB}$.

\section{Perancangan Sistem}

\subsection{Spesifikasi Antena}

Artikel ini difokuskan untuk melakukan analisis nilai-nilai parameter hasil simulasi dari perancangan antena mikrostrip rectangular patch (array 2x2) sebagaimana Gambar 4 dengan teknik pencatuan line feed. Bahan substrate yang digunakan adalah Rogers Duroid 5880 dengan konstanta dielektrik $\varepsilon_{\mathrm{r}}=2,2$ dengan ketebalan $h=0,787 \mathrm{~mm}$, ketebalan copper $(t=$ $0,035 \mathrm{~mm}$. Spesifikasi antena yang dirancang dapat dilihat pada Tabel 1.

Tabel 1. Spesifikasi Antena.

\begin{tabular}{c|c}
\hline Spesifikasi & Deskripsi \\
\hline Frekuensi & $29,25 \mathrm{GHz}$ \\
\hline Impedansi input & $50 \Omega$ \\
\hline Return loss & $\leq-10 \mathrm{~dB}$ \\
\hline Bandwidth & $\geq 1 \mathrm{GHz}$ \\
\hline Gain & $\leq 10 \mathrm{~dB}$ \\
\hline Pola radiasi & Directional \\
\hline Polarisasi & Ellipse \\
\hline
\end{tabular}

\subsection{Skema Perancangan}

Langkah-langkah perancangan antena, mensimulasikan hingga menganalisis dilakukan secara bertahap dan dijelaskan secara singkat seperti Gambar 5.
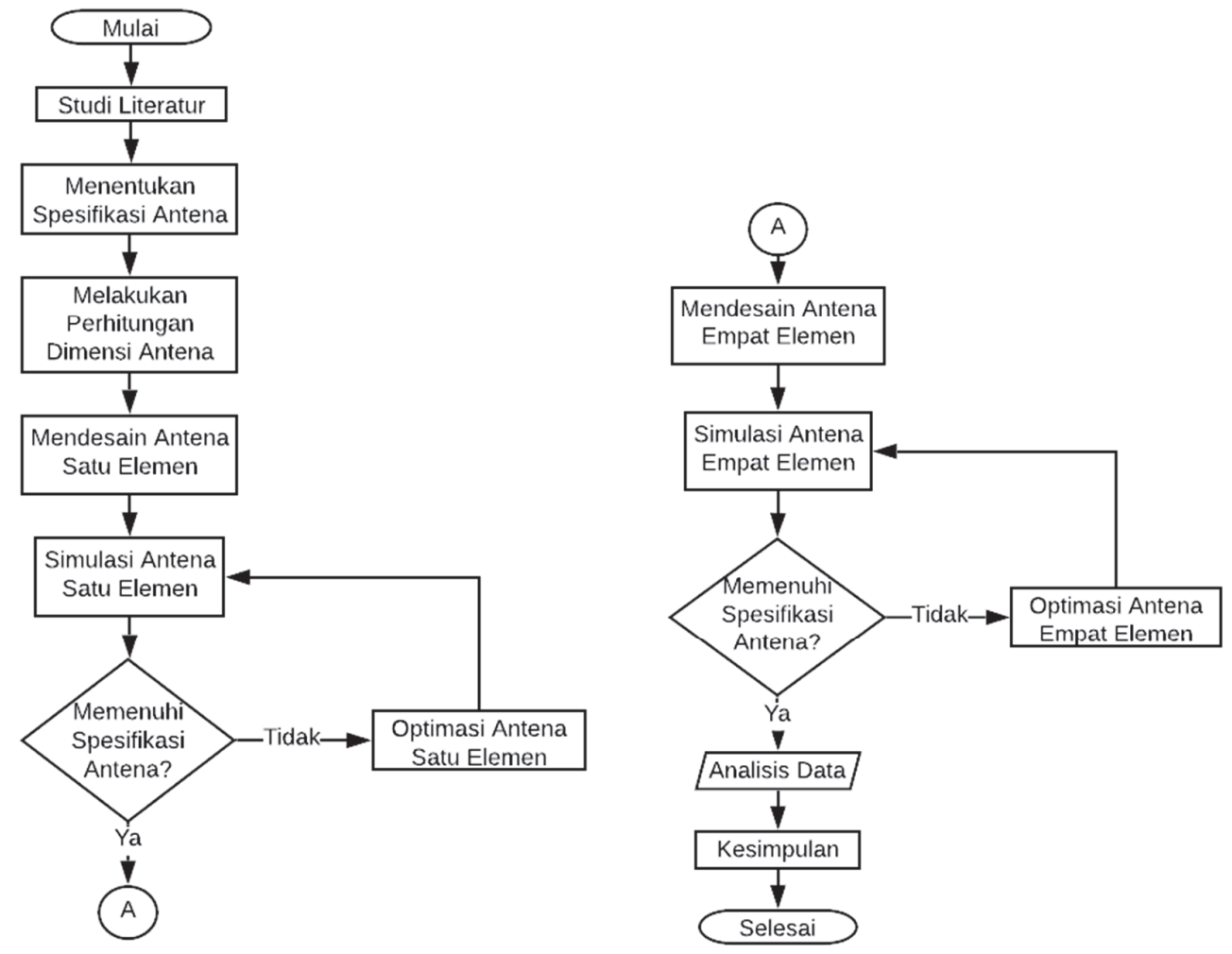

Gambar 5. Diagram Alir Perancangan Antena. 


\subsection{Dimensi dan Desain Antena Satu Elemen}

Berdasarkan perhitungan dengan persamaan-persamaan yang telah dipaparkan dan proses optimasi, maka didapatkan nilai-nilai ukuran dimensi antena satu elemen yang dapat dilihat pada Tabel 2.

Tabel 2. Dimensi Antena Satu Elemen.

\begin{tabular}{c|c|c|c|c}
\hline No. & Parameter & $\begin{array}{c}\text { Ukuran }(\mathrm{mm}) \\
\text { Sebelum Optimasi }\end{array}$ & $\begin{array}{c}\text { Ukuran }(\mathrm{mm}) \\
\text { Setelah Optimasi }\end{array}$ & Keterangan \\
\hline 1. & $W p$ & 4,054 & 4,084 & Lebar patch \\
\hline 2. & $L p$ & 2,906 & 3,206 & Panjang patch \\
\hline 3. & $W f$ & 2,421 & 2,042 & Lebar feed $50 \Omega$ \\
\hline 4. & $L f$ & 1,057 & 1,557 & Panjang feed $50 \Omega$ \\
\hline 5. & $W g$ & 8,776 & 8,106 & Lebar ground plane \\
\hline 6. & $L g$ & 7,628 & 5,812 & Panjang ground plane \\
\hline 7. & хо & 1,055 & 0,9 & Lebar inset feed \\
\hline 8. & уо & 1,0 & 1,099 & Panjang inset feed \\
\hline
\end{tabular}

Pada Gambar 6 menunjukkan hasil rancangan desain antena satu elemen menggunakan antenna design software dengan ukuran dimensi berdasarkan perhitungan pada Tabel 2.

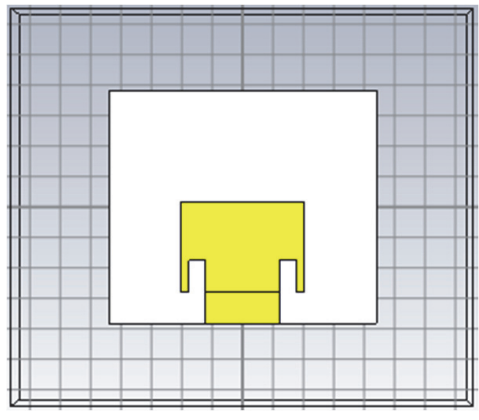

(a) Sebelum Optimasi

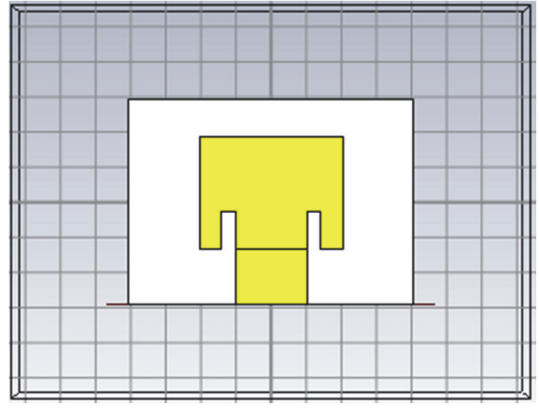

(b) Setelah Optimasi

Gambar 6. Desain Satu Elemen

\subsection{Dimensi dan Desain Antena Empat Elemen}

Sebelum merancang antena empat elemen, harus terlebih dahulu melakukan optimasi antena satu elemen. Setelah berhasil optimasi, ukuran dimensi tersebut dapat digunakan untuk merancang antena empat elemen. Ukuran dimensi antena empat elemen tertera pada Tabel 3. 
Tabel 3. Dimensi Antena Empat Elemen.

\begin{tabular}{c|c|c|c|c}
\hline No. & Parameter & $\begin{array}{c}\text { Ukuran }(\mathrm{mm}) \\
\text { Sebelum Optimasi }\end{array}$ & $\begin{array}{c}\text { Ukuran }(\mathrm{mm}) \\
\text { Setelah Optimasi }\end{array}$ & Keterangan \\
\hline 1. & $W p$ & 4,084 & 4,084 & Lebar patch \\
\hline 2. & $L p$ & 3,206 & 3,206 & Panjang patch \\
\hline 3. & $W f_{1}$ & 2,042 & 1,742 & Lebar feed $50 \Omega$ \\
\hline 4. & $L f_{1}$ & 1,557 & 1,757 & Panjang feed $50 \Omega$ \\
\hline 5. & $W g$ & 8,108 & 8,108 & Lebar ground plane \\
\hline 6. & $L g$ & 5,812 & 5,812 & Panjang ground plane \\
\hline 7. & $\mathrm{x}_{\mathrm{o}}$ & 0,9 & 1,0 & Lebar inset feed \\
\hline 8. & $\mathrm{y}_{\mathrm{o}}$ & 1,099 & 0,899 & Panjang inset feed \\
\hline 9. & $W_{\mathrm{j}}$ & 5,128 & 5,128 & Lebar junction horizontal \\
\hline 10. & $W f_{2}$ & 0,688 & 0,688 & Lebar feed $100 \Omega$ \\
\hline 11. & $L f_{2}$ & 0,87 & 1,07 & Panjang feed $100 \Omega$ \\
\hline 12. & $W f_{3}$ & 1,383 & 1,603 & Lebar feed $70.7 \Omega$ \\
\hline 13. & $L f_{3}$ & 0,974 & 0,974 & Panjang feed $70.7 \Omega$ \\
\hline 14. & $L f_{\mathrm{j}}$ & 1,74 & 2,14 & Panjang junction vertical \\
\hline
\end{tabular}

Gambar 7 merupakan hasil rancangan desain antena empat elemen sesuai ukuran dimensi yang telah ditunjukkan pada Tabel 3 dengan menggunakan antenna design software.

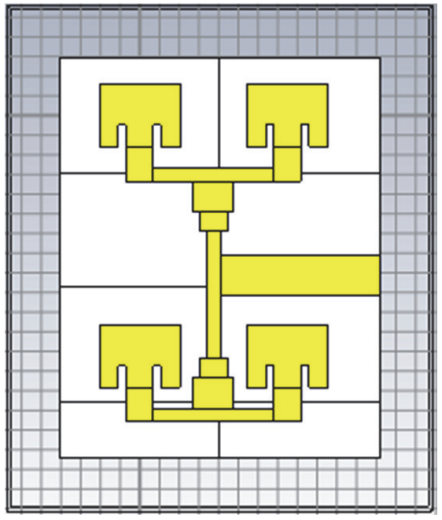

(a) Sebelum Optimasi

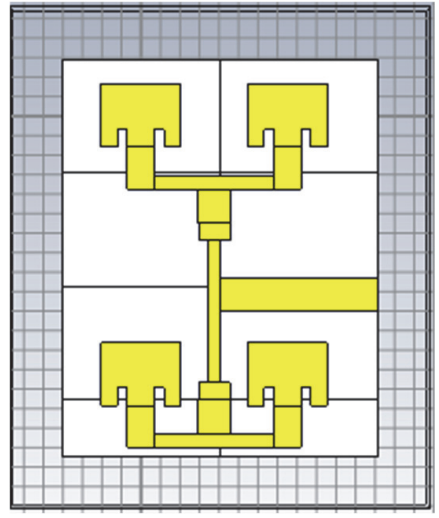

(b) Setelah Optimasi

Gambar 7. Desain Empat Elemen

\section{Hasil dan Analisis}

\subsection{Pengaruh Dimensi Antena Satu Elemen}

Pada hasil simulasi perancangan antena satu elemen berdasarkan perhitungan, didapatkan nilai return loss awal sebesar $-3,116 \mathrm{~dB}$ pada frekuensi 29,25 GHz dengan VSWR bernilai 5,633. Hasil tersebut belum sesuai dengan spesifikasi yang diharapkan.

Oleh karena itu, perlu adanya optimasi. Optimasi dilakukan dengan mengubah dimensi lebar inset feed $\left(\mathrm{x}_{0}\right)$. Dapat dilihat pada Gambar 8 dengan mengubah ukuran $\mathrm{x}_{0}$ semakin kecil, nilai return loss yang dihasilkan akan semakin kecil dimana nilai tersebut memenuhi spesifikasi. 


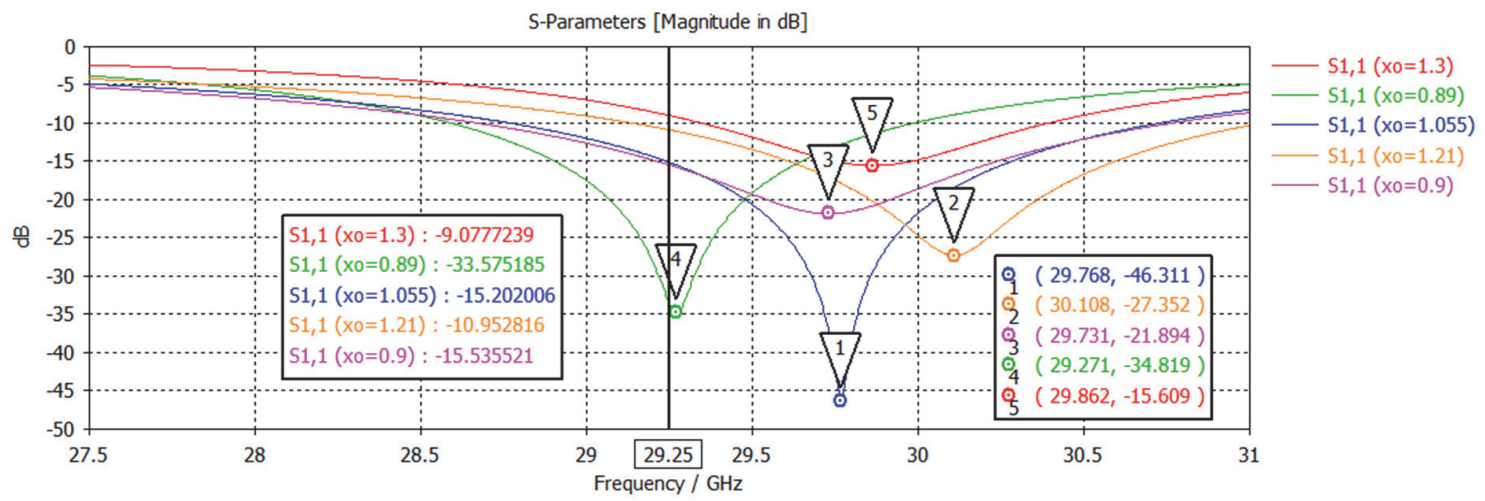

Gambar 8. Optimasi Lebar Inset Feed ( $\mathrm{x}_{\mathrm{o}}$ ) Satu Elemen.

Selain mengubah ukuran dimensi $x_{0}$, diperlukan juga untuk mengubah ukuran dimensi yang lain. Salah satunya adalah mengoptimasi dimensi panjang inset feed ( $\mathrm{y}_{\mathrm{o}}$ ). Dengan mengubah ukuran dimensi yo semakin besar, maka nilai return loss yang dihasilkan akan semakin bagus sebagaimana gambar 9 .

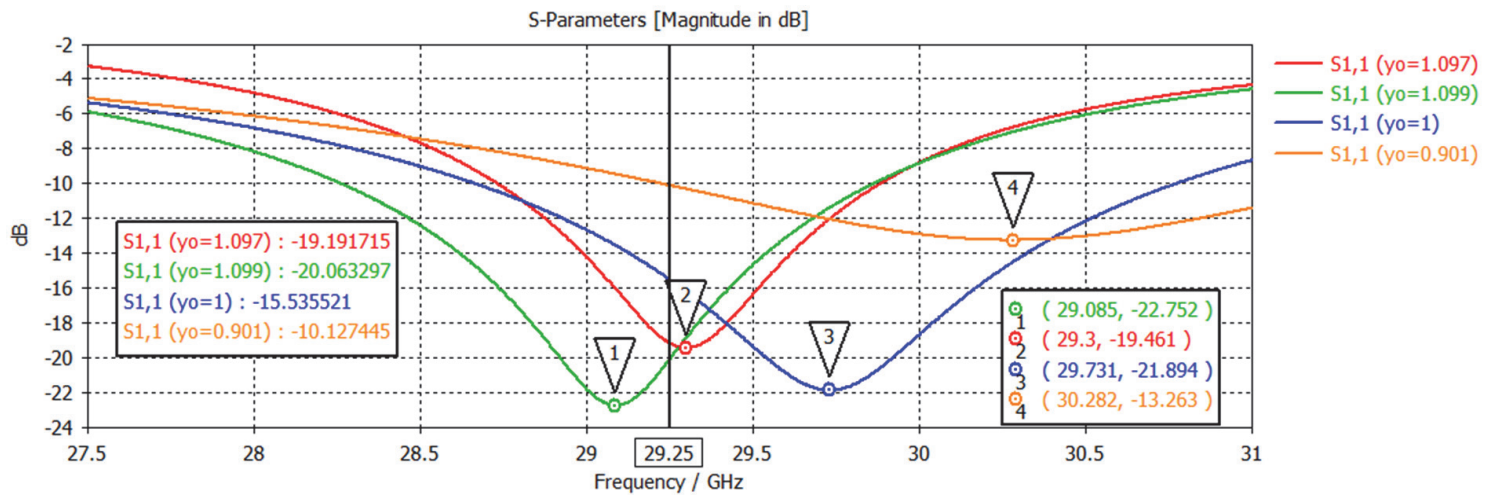

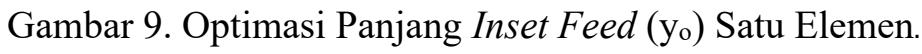

\subsection{Pengaruh Dimensi Antena Empat Elemen}

Hasil simulasi perancangan antena empat elemen berdasarkan perhitungan dan ukuran dimensi hasil optimasi antena satu elemen, diperoleh nilai return loss awal sebesar -7,565 $\mathrm{dB}$ pada frekuensi 29,25 GHz dengan VSWR bernilai 2,439. Hasil simulasi tersebut belum sesuai spesifikasi.

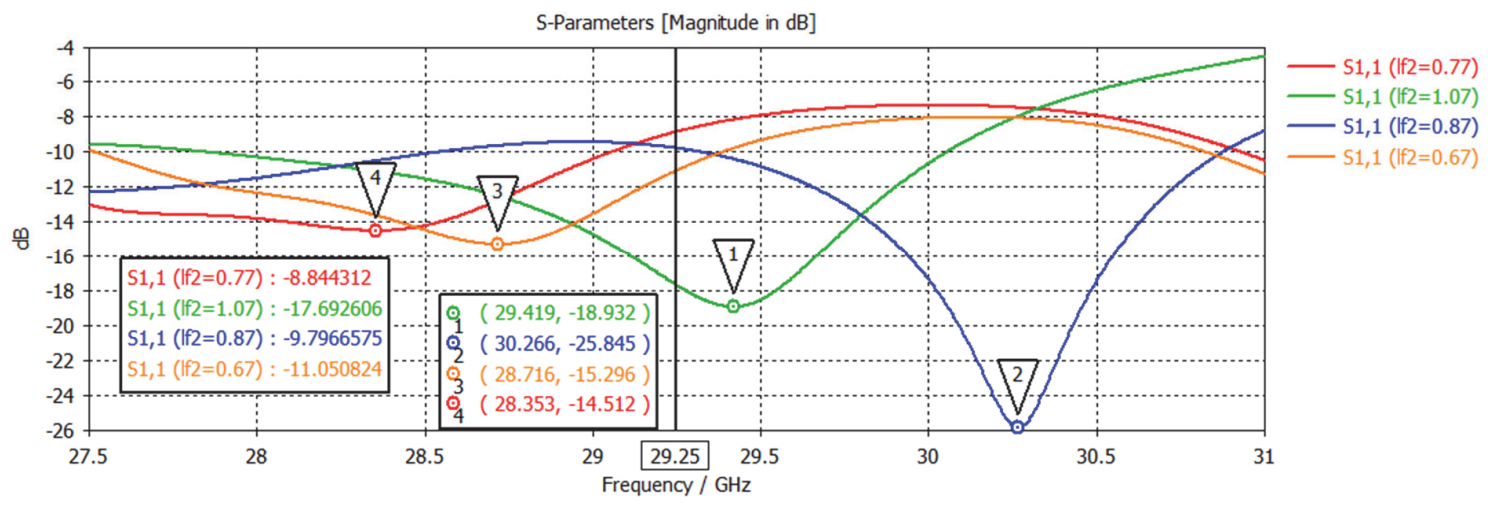

Gambar 10. Optimasi Panjang Line Feed $100 \Omega\left(L f_{2}\right)$ Empat Elemen. 
Maka dari itu perlu dilakukan optimasi dengan mengubah ukuran dimensi antena, salah satunya adalah panjang line feed $100 \Omega\left(L f_{2}\right)$ seperti Gambar 10. Dengan memperbesar ukuran dimensi $L f_{2}$, maka akan semakin kecil nilai return loss yang dihasilkan sebagaimana Gambar 11.

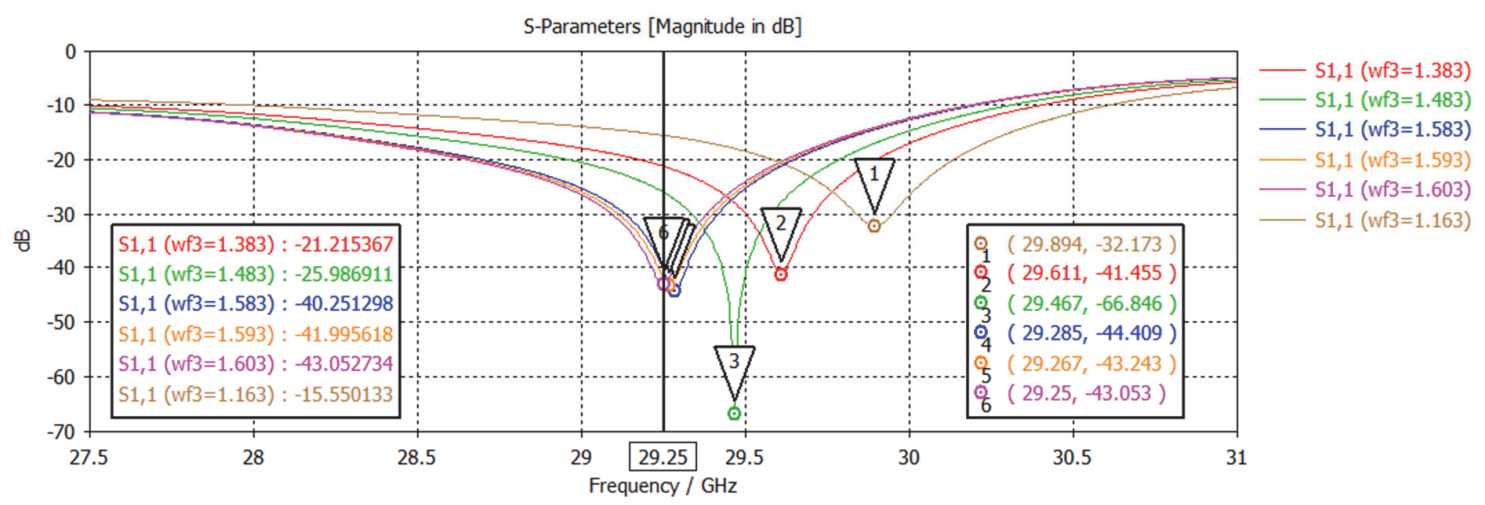

Gambar 11. Optimasi Lebar Line Feed $70.7 \Omega\left(W f_{3}\right)$ Empat Elemen.

Selain itu, optimasi juga dapat dilakukan dengan mengubah ukuran lebar line feed $70.7 \Omega\left(W f_{3}\right)$. Dengan memperbesar ukuran $W f_{3}$, maka nilai return loss akan semakin kecil dan bagus.

\subsection{Hasil Simulasi Setelah Optimasi}

12.

Setelah dilakukan optimasi, didapat pola radiasi empat elemen sebagaimana Gambar

Farfield Gain Abs (Phi=90)

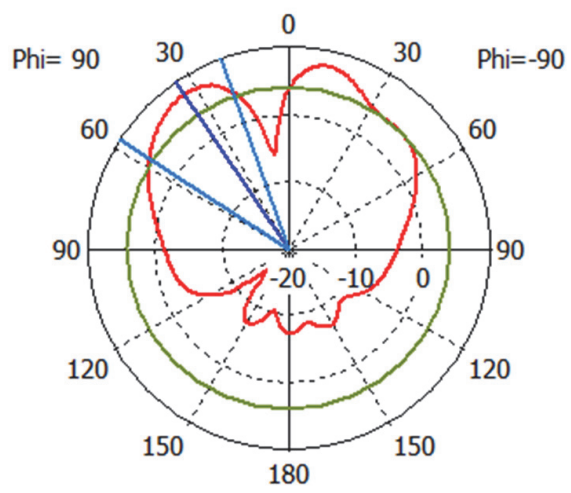

Theta / Degree vs. dB

(a) Elevasi
Farfield Gain Abs (Phi=0)

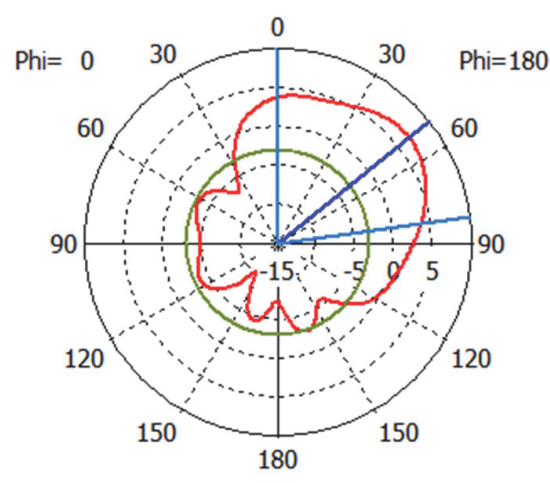

Theta / Degree vs. dB

(b) Azimuth

Gambar 12. Pola radiasi empat elemen setelah optimasi 


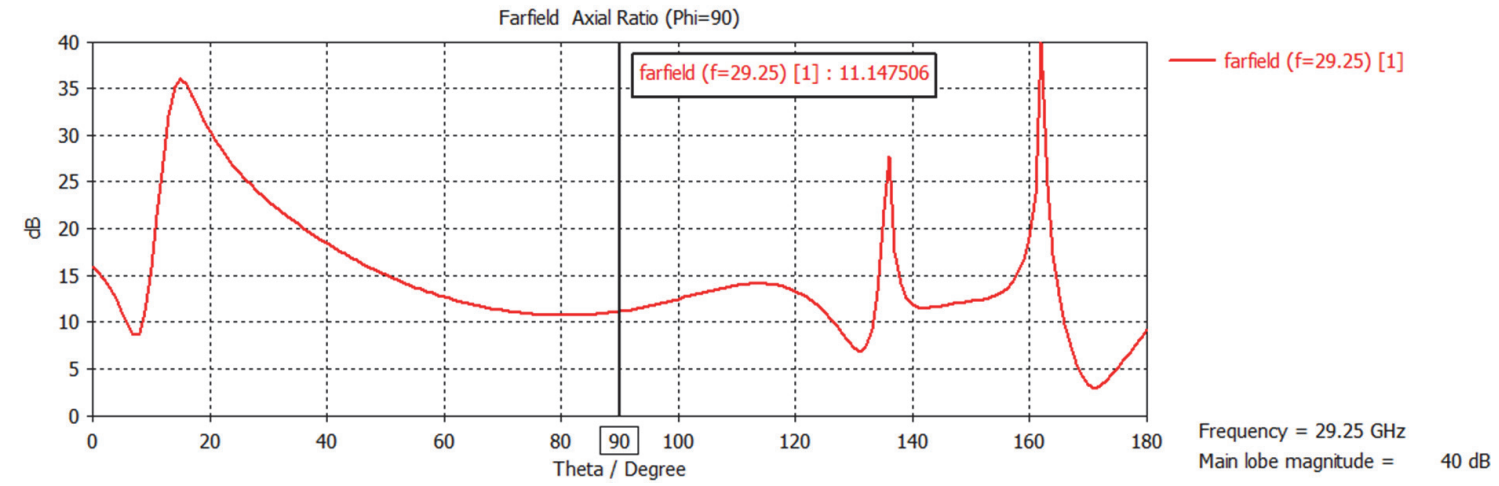

Gambar 13. Polarisasi Empat Elemen Setelah Optimasi.

Setelah dilakukannya proses optimasi pada antena mikrostrip baik untuk satu elemen maupun empat elemen dengan mengubah beberapa ukuran dimensi, maka diperoleh nilai-nilai parameter hasil simulasi yang ditunjukkan pada Tabel 4.

Tabel 4. Hasil Simulasi Setelah Optimasi.

\begin{tabular}{c|c|c|c}
\hline No. & Parameter & Satu Elemen & Empat Elemen \\
\hline 1. & Return loss & $-43,333 \mathrm{~dB}$ & $-43,052 \mathrm{~dB}$ \\
\hline 2. & VSWR & 1,013 & 1,014 \\
\hline 3. & Bandwidth & $1,474 \mathrm{GHz}$ & $2,728 \mathrm{GHz}$ \\
\hline 4. & Gain & $5,593 \mathrm{~dB}$ & $7,823 \mathrm{~dB}$ \\
\hline 5. & Pola radiasi & Directional & Directional \\
\hline 6. & Polarisasi & Linier & Ellipse \\
\hline
\end{tabular}

\section{Kesimpulan}

Kesimpulan yang dapat diambil pada pengerjaan artikel ini dengan merancang dan mendesain antena mikrostrip yang disusun (array) berjumlah empat $(2 \times 2)$ elemen, hingga proses simulasi dan optimasi menggunakan antenna design software, antara lain:

1. Berdasarkan hasil simulasi, diperoleh antena dapat bekerja pada frekuensi $29,25 \mathrm{GHz}$ dengan bandwidth sebesar 2,728 GHz.

2. Spesifikasi antena seperti nilai return loss $\leq-10 \mathrm{~dB}$, pola radiasi directional, dan polarisasi ellipse pada frekeunsi $29,25 \mathrm{GHz}$ dapat memenuhi spesifikasi yang dibutuhkan untuk komunikasi satelit pada Ka-Band.

3. Dengan penambahan jumlah elemen antena dapat meningkatkan nilai gain antena. Pada antena satu elemen nilai gain sebesar 5,593 dB. Sedangkan untuk antena empat elemen nilai gain naik menjadi $7,823 \mathrm{~dB}$.

\section{Daftar Pustaka}

[1] P. O. S. D. A. N. Informatika, K. Komunikasi, and D. A. N. Informatika, (2016). Kajian Frekuensi Ka-band Untuk Komunikasi Satelit.

[2] Elbert, B. R. (2004). The satellite communication applications handbook. Artech house.

[3] Hasanuddin, Z. B. (2014). Design of Ka-band Satellite Links in Indonesia. Journal of Electrical Computer Energetic Electronic and Communication Engineering, 8(8).

[4] Maruddani, B., Kurniawan, A., \& Munir, A. (2011, July). Performance evaluation of Ka-band satellite communication system in rain fading channel at tropical area. In 
Proceedings of the 2011 International Conference on Electrical Engineering and Informatics (pp. 1-5). IEEE.

[5] Sheriff, R. E., \& Hu, Y. F. (2001). Mobile Satellite Communication Networks Mobile Satellite Communication Networks, vol. 845562. University of Bradford United Kingdom.

[6] Balanis, C. A. (2016). Antenna theory: analysis and design. John wiley \& sons

[7] Nugraha, A. S., Christiyono, Y., \& Sukiswo, S. (2011). Perancangan dan Analisa Antena Mikrostrip dengan Frekuensi $850 \mathrm{MHz}$ untuk Aplikasi Praktikum Antena (Doctoral dissertation, Diponegoro University).

[8] A. Harnan Malik, (2014). Antena Mikrostrip; Struktur Dasar Antena Mikrostrip.

[9] Ningsih, R. N. A. R. (2014). Antena Mikrostrip. Teknik Elektronika STT Nusa Putra, [Online]. Available: https://teknikelektronikansp. wordpress. com/2014/01/07/antenamicrostrip-2.

[10] [Online]. Available: https://docplayer.info/docs-images/75/72040212/images/3-1.jpg. [Accessed: 03-Dec-2019].

[11] Alam, S., \& Nugroho, R. F. (2018). Perancangan Antena Mikrostrip Array 2x1 untuk Meningkatkan Gain Untuk Aplikasi LTE Pada Frekuensi 2300 MHz. Elektrokrisna, $6(3)$.

[12] [Online].Available:

https://www.researchgate.net/profile/Glaucio_Lopes_Ramos/publication/305816148/fi gure/fig3/AS:391338609659943@1470313803993/2x2-microstrip-antenna-array.png. [Accessed: 03-Dec-2019].

[13] A. L. Antena, (2019). "Modul Praktikum Antena dan Propagasi 2018 - 2019," pp. 1-35. 